\title{
GENERAL ANESTHESIA EFFECT ON ACID BASE AND SERUM CALCIUM AND PHOSPHORUS LEVELS IN RELATION TO ANESTHETIC RISK IN DOGS
}

\author{
Tomáš Lipták ${ }^{1}$, Valent Ledecký1, Marek Ďurej², Oskar Nagy³, Mária Kuricová \\ ${ }^{1}$ Small Animal Clinic, University of Veterinary Medicine and Pharmacy, \\ Komenskeho 73, 04001 Kosice, Slovak Republic \\ ${ }^{2}$ Veterinary Clinic Tri-Vet, Kaplnská 14, 91943 Cífer, Slovak Republic \\ ${ }^{3}$ Clinic of Ruminants, University of Veterinary Medicine and Pharmacy, \\ Komenskeho 73, 04001 Kosice, Slovak Republic
}

Received 24 November 2016; Received in revised form 18 April 2017; Accepted 3 May 2017

\begin{abstract}
The aim of this study was to investigate the influence of general anesthesia on selected blood parameters in 53 surgical patients belonging to five ASA groups. The venous blood $\mathrm{pH}$ during the preoperative period was under physiological values only in the ASA V group of dogs. The lowest average values of $\mathrm{pH}$ levels were found in all ASA groups during the 30th minute of the surgical procedure. The pre-operative measurements revealed the average concentration of calcium in the blood serum below the physiological range in the groups with higher anesthetic risk, ASA III, IV and V. Most dogs with hypocalcemia during the whole monitored period were in the ASA III group (69.2\%). After premedication and sedation a decrease in the concentration of calcium in all groups was observed, except for the ASA IV group. Changes in the concentration of calcium were significant in the ASA II group $(\mathrm{P} \leq 0.01)$. Between the groups, there were no significant differences reported in calcium concentrations during the monitored period. The lowest average value of phosphorus concentration was recorded in the ASA III group and the highest in the ASA V group. In the postoperative period the increase in phosphorus concentrations was observed in all groups except ASA III. Acidaemia, hypocalcaemia and hyperphosphatemia may present a potential risk mostly in endangered animals, so additional monitoring of these parameters, along with commonly used anesthetic monitoring, is essential and might be significantly helpful.
\end{abstract}

Key words: acid-base, calcium, dog, isoflurane, ketamine, phosphorus

\section{INTRODUCTION}

There is a risk of perioperative mortality related to the anesthesia of small animals. Studies from referrals and university departments have shown a higher risk of mortality compared to the private veterinary practices, due to different characteristics of patients and due to the performing of more complex surgical activities (1). Anesthesia is characterized as a controlled and reversible process.

Corresponding author: Dr. Mária Kuricová, $\mathrm{PhD}$

E-mail address: maria.kuricova@uvlf.sk

Present address: Small Animal Clinic, Department of Surgery,

Orthopaedics, Radiology and Reproduction, University of Veterinary

Medicine and Pharmacy, 04001 Košice, Slovak Republic

Phone: +421915742532 Fax: +421556711674

Copyright: (C) 2017 Lipták T. This is an open-access article published under the terms of the Creative Commons Attribution License which

permits unrestricted use, distribution, and reproduction in any medium, provided the original author and source are credited.

Competing Interests: The authors have declared that no competing

interests exist.

Available Online First: 10 June 2017

Published on: 15 October 2017

https://doi.org/10.1515/macvetrev-2017-0020
Unfortunately, the primary effect of anesthetics is a depressive action on physiological processes (2). The administration of anesthetics produces a controlled and reversible depression of neurologic cortical activity. Unfortunately, the anesthetics also produce adverse effects such as hypotension, hypothermia, and dose-dependent respiratory depression. As a consequence, anesthetics cause hypoxia and acidosis which affect the recovery from anesthesia and they can have fatal implications for critically ill patients (3). One main objective for the anesthetist is to ensure the supply of oxygen to the patient's tissues. The distribution of oxygen in the body is the product of cardiac output and hemoglobin oxygen saturation (4). Phosphate is the main component in the formation of 2,3-diphosphoglycerate (2,3 DPG), which is required for normal oxygen release from hemoglobin to the tissues (5). Inadequate supply of oxygen for cellular metabolism can give rise to lactic acidosis (6). Many papers have documented 
the occurrence of reduced serum calcium concentrations during anesthesia $(7,8,9,10)$, but overall only few studies have focused on serum calcium and phosphorus concentrations in dogs.

The aim of this study was to examine the influence of general anesthesia on the serum levels of total calcium, phosphorus and acid base status in surgical patients and to compare these findings by anesthetic risk as defined by the American Society of Anesthesiologists (ASA).

\section{MATERIAL AND METHODS}

This study included 53 dogs admitted to the Small Animal Clinic which were divided according to the classification defined by the American Society of Anesthesiologists (ASA) into 5 categories of surgical risk (ASA I-V) (12) based on the signalment, history of underlying diseases or surgeries and of previous or current medical treatment of symptoms of various illnesses (burden intolerance, cough, diarrhea, vomiting, etc.), based on the body condition score (BCS, grades 1-5) and others $(11,12)$.

For premedication and sedation Medetomidine (Cepetor KH 1mg/ml, CP-Pharma, Germany) was used in a dose of $10-20 \mu \mathrm{g} / \mathrm{kg}$ intramuscularly, Butorphanol (Butomidor 10mg/ml, Richterpharma, Austria) $0.2-0.4 \mathrm{mg} / \mathrm{kg}$ or Morphine (Morphin 1\% Biotika, BB Pharma, Slovakia) $0.4-0.8 \mathrm{mg} / \mathrm{kg}$, and Diazepam (Apaurin 10mg/2ml, Krka, Slovenia) in the dose of $0.3 \mathrm{mg} / \mathrm{kg}$. For induction Ketamine (Narketan 10, Vétoquinol, France) was used intravenously in a dose of $4-5 \mathrm{mg} / \mathrm{kg}$.

General anesthesia was maintained via inhalation with a mixture of Isoflurane (Forane, Abbott, UK) and the low flow oxygen via an inhalation device Komesaroff Mini-Com (Australia) with vaporizerincirquit. No dog was ventilated by means of a mechanical ventilator during general anesthesia. When needed, for patients in ASA IV and V we used ventilation with positive pressure manually. Infusion therapy in the perioperative period was provided $0.9 \% \mathrm{NaCl}(5-10 \mathrm{ml} / \mathrm{kg} /$ hour$)$. For the groups ASA IV and ASA V, the dosing was $60-90 \mathrm{ml} / \mathrm{kg} /$ hour. Dosage and route of administration (s.c., i.m., i.v.) of each anesthetic was adjusted according to the individual patient and clinical circumstances. After premedication for analgesia in orthopedic patients we used Morphine and in every other patients Butorphanol. For patients in the ASA IV and ASA $\mathrm{V}$ groups, we did not use Medetomidine as a part of the premedication. Blood collection to analyze the concentration of calcium and phosphorus in the blood serum (volume $1 \mathrm{ml}$ ) was performed from the peripheral veins - v. cephalica antebrachii, v. saphena lateralis. Blood serum was obtained after centrifugation of clotted blood for 10 minutes at 3500rpm. Blood collection was performed preoperatively before administration of sedatives and anesthetics (T0), under general anesthesia during the surgery in the 30th minute (T1) and 120 minutes after the end of surgery (T2). Evaluated parameters were measured with automated analyzator Cobas c111 Roche (Switzerland) using diagnostic tests Roche (Switzerland). The physiological range values defined for calcium were $2.05-2.86 \mathrm{mmol} / 1$ and for phosphorus $0.90-1.91 \mathrm{mmol} / 1$ (13). Blood for acid base analysis was collected anaerobically into the capillary tube (volume $200 \mu \mathrm{l}$ ) containing heparin lithium and analyzed immediately after collection without storing samples with blood gas analyzer (Easy Medica Blood Gas, GMI, USA). Physiological $\mathrm{pH}$ values of venous blood were set at 7.32-7.40 (14).

Data was processed and analyzed according to the evaluated end points, groups of animals and time periods. The results were processed by stating mean values and standard deviations (SD). The significance of changes during individual perioperative periods was analyzed with Friedman (F) non-parametric test. Significance of differences between groups of dogs (ASA I to ASA V) was analyzed with KruskalWallis (K-W) non-parametric test. In both cases, we used Dunn's comparative post-test. Statistical analysis was performed using statistical software GraphPad Prism version 3.0. Results were considered statistically significant if $\mathrm{P}<0.05$.

\section{RESULTS}

The group ASA I consisted of 13 patients (8 females and 5 males). This group contained surgical patients not showing any signs of internal diseases and which were in a good physical condition. This group of dogs was set as a control group. The average duration of the surgical procedure - the anesthetic time for this group was 71 minutes. Group ASA II included 13 patients ( 7 females and 6 males). The average duration of the surgical procedure was 65 minutes. The ASA III group comprised of 13 patients (10 females and 3 males) and the average duration was 75 minutes. In the ASA IV group there were 7 patients ( 3 females and 4 males) affected with serious medical conditions. The average duration of the surgical procedure was 60 minutes. In the ASA V group there were 7 polytraumatic patients ( 5 females, 2 males) and the average duration of the surgical procedure was 45 minutes. Detailed description of patients and operative procedures is given in Table 1. 
Table 1. Preoperative distribution of dogs in the ASA groups and their characteristics

\begin{tabular}{|c|c|c|c|c|}
\hline Group & Breed & Age (months) & $\mathrm{BCS}$ & Surgery \\
\hline \multirow{13}{*}{ ASA I. } & Leonberger & 12 & $4 / 5$ & Orthopedics \\
\hline & Golden Retriever & 7 & $3 / 5$ & Orthopedics \\
\hline & Golden Retriever & 10 & $3 / 5$ & Orthopedics \\
\hline & Golden Retriever & 72 & $4 / 5$ & Orthopedics \\
\hline & Labrador Retriever & 24 & $4 / 5$ & Orthopedics \\
\hline & Cane Corso & 14 & $4 / 5$ & Orthopedics \\
\hline & Fox Terrier & 5,5 & $3 / 5$ & Orthopedics \\
\hline & Bichon & 84 & $3 / 5$ & Orthopedics \\
\hline & Central Asian Shepherd & 36 & $3 / 5$ & Arthroscopy \\
\hline & Maltese & 66 & $3 / 5$ & Endodontics \\
\hline & Mongrel & 24 & $3 / 5$ & Endodontics \\
\hline & Mongrel & 24 & $3 / 5$ & Endodontics \\
\hline & German Shepherd & 10 & $3 / 5$ & Gonadectomy \\
\hline Mean & body weight $24.2 \mathrm{~kg}$ & age 30 & & duration 71 minutes \\
\hline \multirow{13}{*}{ ASA II. } & Leonberger & 9 & $3 / 5$ & Orthopedics \\
\hline & Rottweiler & 60 & $4 / 5$ & Orthopedics \\
\hline & Golden Retriever & 132 & $4 / 5$ & Orthopedics \\
\hline & Golden Retriever & 126 & $4 / 5$ & Orthopedics \\
\hline & Boxer & 96 & $3 / 5$ & Orthopedics \\
\hline & Mongrel & 120 & $3 / 5$ & Orthopedics \\
\hline & Jack Russel Terrier & 7 & $3 / 5$ & Orthopedics \\
\hline & Pug & 30 & $4 / 5$ & Orthopedics \\
\hline & Magyar Vizsla & 96 & $3 / 5$ & Mastectomy \\
\hline & Mongrel & 84 & $3 / 5$ & Skin tumor extirpation \\
\hline & German Spitz & 36 & $3 / 5$ & Laparotomy \\
\hline & Mongrel & 96 & $3 / 5$ & Periodontics \\
\hline & German Shepherd & 84 & $3 / 5$ & Ovariohysterectomy \\
\hline Mean & body weight $24.1 \mathrm{~kg}$ & age 74 & & duration 65 minutes \\
\hline \multirow{13}{*}{ ASA III. } & Slovakian Hound & 132 & $3 / 5$ & Mastectomy \\
\hline & Schnauzer & 132 & $3 / 5$ & Mastectomy \\
\hline & Poodle & 96 & $3 / 5$ & Mastectomy \\
\hline & Pug & 72 & $3 / 5$ & Mastectomy \\
\hline & Doberman & 132 & $3 / 5$ & Skin tumor extirpation \\
\hline & Boxer & 96 & $3 / 5$ & Skin tumor extirpation \\
\hline & American Cocker Spaniel & 150 & $4 / 5$ & Skin tumor extirpation \\
\hline & Dachshund & 162 & $4 / 5$ & Skin tumor extirpation \\
\hline & Yorkshire Terrier & 120 & $3 / 5$ & Skin tumor extirpation \\
\hline & Bavarian Hound & 108 & $3 / 5$ & Wound closure \\
\hline & Mongrel & 18 & $2 / 5$ & Laparotomy \\
\hline & Yorkshire Terrier & 30 & $3 / 5$ & Laparotomy \\
\hline & English Cocker Spaniel & 102 & $3 / 5$ & Laparotomy \\
\hline Mean & body weight $15.2 \mathrm{~kg}$ & age 104 & & duration 75 minutes \\
\hline \multirow{6}{*}{ ASA IV. } & Carry Blue Terrier & 48 & $3 / 5$ & Orthopedics (with shock) \\
\hline & Dogue de Bordeaux & 72 & $2 / 5$ & Laparotomy \\
\hline & Golden Retriever & 126 & $4 / 5$ & Laparotomy \\
\hline & Slovakian Hound & 15 & $2 / 5$ & Laparotomy \\
\hline & Mongrel & 4 & $2 / 5$ & Laparotomy \\
\hline & Mongrel & 36 & $3 / 5$ & Laparotomy \\
\hline Mean & body weight $20.9 \mathrm{~kg}$ & age 58 & & duration 60 minutes \\
\hline \multirow{7}{*}{ ASA V. } & German Shepherd & 132 & $3 / 5$ & Laparotomy \\
\hline & Rhodesian Ridgeback & 48 & $3 / 5$ & Laparotomy \\
\hline & Basset Hound & 60 & $3 / 5$ & Laparotomy \\
\hline & Bavarian Mountain Dog & 8 & $3 / 5$ & Laparotomy \\
\hline & WHW Terrier & 96 & $3 / 5$ & Laparotomy \\
\hline & German Spitz & 24 & $3 / 5$ & Laparotomy \\
\hline & Bichon & 48 & $3 / 5$ & Laparotomy \\
\hline Mean & body weight $21.8 \mathrm{~kg}$ & age 59 & & duration 45 minutes \\
\hline
\end{tabular}


The venous blood $\mathrm{pH}$ during the preoperative period (T0) was under the physiological values only in the ASA V group of dogs (Table 2). Significant changes in the $\mathrm{pH}$ levels during the reporting period were recorded in the ASA I, ASA II, and ASA III group $(\mathrm{P}<0.001)$. Venous $\mathrm{pH}$ was significantly lower in ASA V as compared to ASA I, ASA II and ASA III. The lowest average values of $\mathrm{pH}$ were found in all groups during the surgical procedure (at the 30th minute). 120 minutes after the surgical procedure, the rise of blood $\mathrm{pH}$ was seen in all groups except for the ASA V.

The pre-operative measurements revealed that the average concentration of calcium in the blood serum was below the physiological range in the groups ASA III, IV and V (Table 3). Most dogs with hypocalcemia during the whole period were in the ASA III group (69.2\%). After induction of general anesthesia (in the 30th minute), a decrease in the concentration of calcium was observed in all groups, except the ASA IV group. Changes in the concentration of calcium were significant in the ASA II group of dogs $(\mathrm{P}<0.01)$, while mean values after induction of general anesthesia were within the normal range.

The average concentrations of phosphorus in the serum of all groups of dogs was in the physiological range preoperatively. The lowest average value was recorded in the ASA III group of dogs and the highest in the ASAV group of dogs (Table 4). Changes in phosphorus concentrations during the monitored period were significant in groups ASA I $(\mathrm{P}<0.01)$, ASA II $(\mathrm{P}<0.001)$, and ASA III $(\mathrm{P}<0.01)$. No significant differences in the serum phosphorus level were found between the groups at any of the monitored time periods.

Table 2. Blood $\mathrm{pH}$ levels in the ASA groups of dogs in perioperative period (mean $\pm \mathrm{SD}$ )

\begin{tabular}{ccccccc}
\hline \multirow{2}{*}{$\begin{array}{c}\text { Time of blood } \\
\text { collection }\end{array}$} & ASA I & ASA II & ASA III & ASA IV & ASA V & K-W \\
\cline { 2 - 7 } & $7.39 \pm 0.03^{\mathrm{a}}$ & $7.40 \pm 0.04^{\mathrm{b}, \mathrm{d}}$ & $7.40 \pm 0.04^{\mathrm{c}, \mathrm{d}}$ & $7.33 \pm 0.15$ & $7.25 \pm 0.09^{\mathrm{a}, \mathrm{b}, \mathrm{c}}$ & $\mathrm{P}<0.01$ \\
\hline T0 & $7.23 \pm 0.05^{\mathrm{d}}$ & $7.25 \pm 0.04^{\mathrm{d}}$ & $7.25 \pm 0.05^{\mathrm{d}}$ & $7.24 \pm 0.08$ & $7.19 \pm 0.11$ & $\mathrm{~ns}$ \\
\hline T1 & $7.35 \pm 0.03^{\mathrm{d}}$ & $7.33 \pm 0.05$ & $7.32 \pm 0.06$ & $7.31 \pm 0.04$ & $7.28 \pm 0.08$ & $\mathrm{~ns}$ \\
\hline $\mathbf{T} 2$ & 0.001 & 0.001 & 0.001 & $\mathrm{~ns}$ & $\mathrm{~ns}$ & \\
\hline $\mathbf{F}$ & $\mathbf{P}<$ & &
\end{tabular}

The same index in the row represents the significance of the differences between the ASA groups tested with Kruskall-Wallis test (K-W). Significances were found at T0 (a: $\mathrm{P}<0.01 ; \mathrm{b}, \mathrm{c}: \mathrm{P}<0.001$; T0 - before surgery, T1 - during the operation in 30th min., T2 - $120 \mathrm{~min}$. after surgery, ns - not significant). Changes during time were tested for each group with the Friedman test $(\mathrm{F})(\mathrm{d}: \mathrm{P}<0.001)$

Table 3. Measured calcium concentrations in blood serum (mean $\pm \mathrm{SD}$ )

\begin{tabular}{ccccccc}
\hline \multirow{2}{*}{$\begin{array}{c}\text { Time of blood } \\
\text { collection }\end{array}$} & ASA I & ASA II & ASA III & ASA IV & ASA V & K-W \\
\cline { 2 - 7 } & $2.14 \pm 0.48$ & $2.23 \pm 0.35^{\mathrm{a}}$ & $1.92 \pm 0.29$ & $1.75 \pm 0.39$ & $1.91 \pm 0.48$ & $\mathrm{~ns}$ \\
\hline T0 & $2.07 \pm 0.44$ & $2.08 \pm 0.30^{\mathrm{a}, \mathrm{b}}$ & $1.80 \pm 0.22$ & $1.77 \pm 0.32$ & $1.88 \pm 0.45$ & $\mathrm{~ns}$ \\
\hline T1 & $2.10 \pm 0.35$ & $2.19 \pm 0.35^{\mathrm{b}}$ & $1.92 \pm 0.29$ & $1.81 \pm 0.36$ & $1.91 \pm 0.39$ & $\mathrm{~ns}$ \\
\hline T2 & $\mathrm{ns}$ & 0.01 & $\mathrm{~ns}$ & $\mathrm{~ns}$ & $\mathrm{~ns}$ &
\end{tabular}

The same index in the column indicates the significance of changes between time points in ASA II group (T0 - before surgery, T1 during the surgery in 30th min., T2 - 120 min. after surgery; a, b: $\mathrm{P}<0.01)$ tested with the Friedman test $(\mathrm{F})$, no difference was found between groups (K-W - Kruskall-Wallis test, ns - not significant) 
Table 4. Measured phosphorus concentrations in the blood serum (mean \pm SD)

\begin{tabular}{ccccccc}
\hline \multirow{2}{*}{$\begin{array}{c}\text { Time of blood } \\
\text { collection }\end{array}$} & ASA I & ASA II & ASA III & ASA IV & ASA V & K-W \\
\cline { 2 - 7 } & $1.22 \pm 0.48^{\mathrm{a}, \mathrm{b}}$ & $1.09 \pm 0.19^{\mathrm{b}, \mathrm{c}}$ & $0.99 \pm 0.39^{\mathrm{b}}$ & $2.03 \pm 1.91$ & $2.79 \pm 1.48$ & $\mathrm{~ns}$ \\
\hline T0 & $1.53 \pm 0.40^{\mathrm{b}}$ & $1.36 \pm 0.37^{\mathrm{c}}$ & $1.17 \pm 0.37$ & $2.16 \pm 1.80$ & $3.00 \pm 1.81$ & $\mathrm{~ns}$ \\
\hline T1 & $1.46 \pm 0.52^{\mathrm{a}}$ & $1.30 \pm 0.27^{\mathrm{b}}$ & $1.39 \pm 0.39^{\mathrm{b}}$ & $1.92 \pm 1.08$ & $2.79 \pm 1.48$ & $\mathrm{~ns}$ \\
\hline T2 & 0.01 & 0.001 & 0.01 & $\mathrm{~ns}$ & $\mathrm{~ns}$ & \\
\hline
\end{tabular}

The same index in the column indicates the significance of the comparison $(\mathrm{a}: \mathrm{P}<0.05, \mathrm{~b}: \mathrm{P}<0.01, \mathrm{c}: \mathrm{P}<0,001, \mathrm{~T} 0$ - before surgery, $\mathrm{T} 1$ - during the surgery (30th min.), T2 - $120 \mathrm{~min}$. after surgery, ns - not significant. Changes between groups were tested with Kruskall-Wallis test $(\mathrm{K}-\mathrm{W})$, changes during time with Friedman test (F)

\section{DISCUSSION}

After admission of dogs to the clinic, history collection and clinical examination was performed for each dog. Medetomidine (except for groups ASA IV and V) and Butorphanol were administered, which are known to cause significant, doserelated increase of $\mathrm{PaCO}_{2}$ and a decrease of $\mathrm{PaO}_{2}$ and the $\mathrm{pH}$ values of blood $(15,16,17)$. This fact could partially affect the results of our study. In the available literature there are only a few studies dealing with effects of anesthesia and surgical procedures on the concentration of calcium and phosphorus in animals. Much of the information is taken from human medicine and use the ionized calcium level. In the study conducted by Aguilera and Vaughan in 2000 (10) it was found that the value of ionized calcium is affected by changes in blood $\mathrm{pH}$. Low levels of serum calcium below the physiological margins were recorded preoperatively in the ASA III, IV, and V groups in our study. After administration of anesthetics the concentration dropped even more, which may present a potential risk factor. The ASA III group of dogs consisted mostly of oncological patients and this group is characterized by the highest average age of dogs. In general, the occurrence of hypercalcemia is reported in patients at the time point when the neoplastic process is already apparent and it may occur in approximately $10 \%$ of malignant cancer patients according to literature (18). In our group of cancer patients hypocalcaemia was measured, which worsened during the surgical procedure. Intraoperative or postoperative hypocalcemia has been previously observed by several authors and was attributed to inhalation anesthesia in humans, dogs and horses $(7,19,20,21)$. This decrease in calcium concentration could be caused by the premedication or induction of anesthesia. In studies when different anesthetic protocols were used including opioids, benzodiazepines, ketamine, and isoflurane (22) there was a significant reduction in arterial and venous concentrations of ionized calcium in healthy dogs during general anesthesia lasting less than three and a half hours. In addition, acidosis and hypocalcaemia commonly occur in critically ill dogs $(23,24,25)$ and according to some authors also during the general anesthesia $(8$, $26,27)$.

In this study we recorded an increase in phosphorus concentrations in all groups of dogs after administration of anesthetics. A significant rise in the phosphorus was observed in the ASA I, II, and III groups of dogs. Changes in plasma concentration of phosphorus during anesthesia with ketamine and diazepam have been previously observed in 2003 by Gonzáles-Gil et al. (28). Later in 2010 GonzálesGil et al. (29) published a study on healthy rabbits where after administration of isoflurane there was a reduction in serum calcium and an increase in phosphorus concentrations, which is what was observed in our study. Shiber and Mattu in 2002 (5) have suggested that hyperphosphatemia may be caused by hypomagnesemia, hypernatremia and metabolic acidosis. Hyperphosphatemia could be also due to young age of patients $(30,31)$ which is true for the first group of dogs (ASA I) in our study.

In the case of dropped phosphorus concentration (32), the authors did not conclusively state that hypophosphatemia may be indicative of an emerging sepsis. The groups in our study did not include any patients with sepsis. In one dog in the ASA I group alkalosis and hypophosphatemia occurred in the preoperative period.

This study has several limitations, namely the small and different numbers of patients in each 
group and the fact that there was no measurement of ionized calcium. These results are indicative and further prospective studies are needed to verify the full impact of the severity of condition.

\section{CONCLUSION}

Following the administration of sedatives and anesthetics, acidaemia occurred in all dogs and significant changes in the serum calcium levels were observed. The lowest levels of calcium during the whole perioperative period were detected in patients with skin and mammary cancers, although no patient suffered from serious hypercalcemia or hypocalcemia. Influence of anesthesia led to a significant increase in the concentration of phosphorus, but the values remained within the physiological range. Further prospective studies are needed to verify the full impact of the severity of these conditions.

\section{CONFLICT OF INTEREST STATEMENT}

The authors declared that they have no potential conflict of interest with respect to the authorship and/or publication of this article

\section{ACKNOWLEDGEMENT}

This study was realised by the project Medical University Park in Košice (MediPark, Košice) ITMS:26220220185 supported by Operational Programme Research and Development (OP VaV2012/2.2/08-RO) (Contract No. OPVaV/12/2013) and it was supported by the financial support from the Scientific Grant Agency of the Ministry of Education, Science, Research and Sport of the Slovak Republic and the Slovak academy of Sciences (VEGA no. 1/0898/15).

\section{REFERENCES}

1. Brodbelt, D. (2009). Perioperative mortality in small animal anaesthesia. Vet J. 182, 152-161. https://doi.org/10.1016/j.tvj1.2008.06.011 PMid:18658000

2. Harvey, R.C. (1999). Anaesthetic emergencies and complications. In: Seymour CH., Gleed R. (Ed.), Manual of small animal anaesthesia and analgesia (pp. 257). BSAVA.

PMid:10474515 PMCid:PMC501328
3. Wilson, D.V. (1992). Anesthesia for patients with diaphragmatic-hernia and severe dyspnea. Vet Clin North Am Small Anim. Pract. 22, 456-459. https://doi.org/10.1016/S0195-5616(92)50670-2

4. Byrne, A.J. (2007). Monitoring. In: A.R. Aitkenhead (Ed.), Textbook of anaesthesia. 5th ed. (pp. 858). Churchill Livingstone.

5. Shiber, J.R., Mattu, A. (2002). Serum phosphate abnormalities in the emergency department. J Emerg Med. 23, 395-400. https://doi.org/10.1016/S0736-4679(02)00578-4

6. Morisaki, H., Sibbald, W.J. (2004). Tissue oxygen delivery and the microcirculation. Crit Care Clin. 20, 213-223.

https://doi.org/10.1016/j.ccc.2003.12.003 PMid:15135461

7. Catinella, F.P., Cunningham, J.N., Strauss, E.D., Adams, P.X., Laschinger, J.C., Spencer, F.C. (1983). Variations in total and ionized calcium during cardiac surgery. J Cardiovasc Surg. 24, 593-602.

8. Cote, C.J. (1987). Depth of halothane anesthesia potentiates citrate-induced ionized hypocalcemia and adverse cardiovascular events in dogs. Anesthesiology 67, 676-680.

https://doi.org/10.1097/00000542-198711000-00010 PMid:3674467

9. Lepage, R., Lepage, G., Racicot, C. (1999). Hypocalcemia induced during major and minor abdominal surgery in humans. J Clin Endocrinol Metab. 84, 2654-2658. https://doi.org/10.1210/jcem.84.8.5889 PMid:10443655

10. Aguilera, I.M., Vaughan, R.S. (2000). Calcium and the anesthetists. Anaesthesia 55, 779-790. https://doi.org/10.1046/j.1365-2044.2000.01540.x PMid:10947693

11. Lund,E.M.,Armstrong,P.J.,Kirk, C.A.,Klausner,J.S. (2006). Prevalence and risk factors for obesity in adult dogs from private US veterinary practices. Intern J Appl Res Vet Med. 4, 177-186.

12. Hall, L.W. (2001). General considerations. In: L.W. Hall, K.W. Clarke, C.M. Trim (Ed.), Veterinary anaesthesia. 10th ed. (pp. 1-26). Saunders. https://doi.org/10.1016/B978-070202035-3.50002-4 PMCid:PMC101120

13. Tučková, M. (2011). Biochemical profile of dog and cat. In: Team of authors. Practical guide for veterinary doctors (pp. 7-107). Veterinary Chamber of the Slovak Republic.

14. Kučera, J. (2008). Urinary system. In: M. Kozák (Ed.), Diseases of dogs and cats (internal, infectious, parasitary). Košice: University of veterinary medicine. 
15. Kuo, W.C., Keegan, R.D. (2004). Comparative cardiovascular, analgesic, and sedative effects of medetomidine, medetomidine-hydromorphone, and medetomidine-butorphanol in dogs. Am J Vet Res. 65, 931-937.

https://doi.org/10.2460/ajvr.2004.65.931

PMid:15281651

16. Lerche, P., Muir, W.W. (2004). Effect of medetomidine on breathing and inspiratory drive in conscious dogs. Am J Vet Res. 65, 720-734.

https://doi.org/10.2460/ajvr.2004.65.720

PMid:15198209

17. Raekallio, M.J., Räihä, M.P., Alanen, M.H., Sarén, N.M., Tuovio, T.A. (2009). Effects of medetomidine, L-methadone, and their combination on arterial blood gases in dogs. Vet Anaest Analg. 36, 158-161. https://doi.org/10.1111/j.1467-2995.2008.00444.x PMid:19239654

18. Mason, R. (1994). Anesthesia data book: A clinical practice compendium. 2nd ed. (pp. 241-243). Churchill Livingstone.

PMid:8035910

19. Haleem, S., Ansari, M.M., Shakoor, A., Bano, S. (1990). Prospective study of changes in serum calcium after diethylether anesthesia. Indian J Med Res. 92, 192-194.

PMid:2401540

20. Hysing, E.S., Chelly, J.E., Jacobson, L., Doursout, M.F., Merin, R.G. (1990). Cardiovascular effects of acute changes in extracellular ionized calcium concentration induced by citrate and $\mathrm{CaCl} 2$ infusions in chronically instrumented dogs, conscious and during enflurane, halothane, and isoflurane anesthesia. Anesthesia 72, 100-104. https://doi.org/10.1097/00000542-199001000-00018

21. Grubb, T.L., Benson, G.J., Foreman, J.H., Constable, P.D., Thurmon, J.C., Olson, W.O., Tranquilli, W.J., Davis, L.E. (1999). Hemodynamic effects of ionized calcium in horses anesthetized with halothane or isoflurane. Am J Vet Res. 60, 1430-1435.

PMid:10566822

22. Brainard, B.M., Campbell, V.L., Drobatz, K.J., Perkowski, S.Z. (2007). The effect of surgery and anesthesia on blood magnesium and calcium concentrations in canine and feline patients. Vet Anaesth Analg. 34, 89-98.

https://doi.org/10.1111/j.1467-2995.2006.00300.x PMid:17316389

23. Macintire, D.K. (1995) Emergency therapy of diabetic crisis: insulin overdose, diabetic ketoacidosis and hyperosmolar coma. Vet Clin North Am Small Anim Pract. 25, 639-650.

https://doi.org/10.1016/S0195-5616(95)50059-2

24. Vaden, S.L., Levine, J., Breitschwerdt, E.B. (1997). A retrospective case control of acute renal failure in 99 dogs. J Vet Intern Med. 11, 58-64. https://doi.org/10.1111/j.1939-1676.1997.tb00074.x PMid:9127291

25. King, L.G., Wohl, J.S., Manning, A.M., Hackner, S.G., Raffe, M.R., Maislin, G. (2001). Evaluation of the survival prediction index as a model of risk stratification for clinical research in dogs admitted to intensive care units at four locations. Am J Vet Res. 62, 948-954.

https://doi.org/10.2460/ajvr.2001.62.948

PMid:11400855

26. Otto, K.A., Weber, B.P., Jacobi, M., Hedrich, H.J. (1997). Retrospective evaluation of cardiopulmonary and acid-base variables during long-term balanced anesthesia for experimental surgery in dogs. Lab Anim Sci. 47, 624-631.

PMid:9433699

27. Gronert, G.A., Haskins, S.C., Steffey, E.P. (1998). Plasma electrolyte and metabolite concentrations associated with pentobarbital or pentobarbital-propofol anesthesia during three weeks' mechanical ventilation and intensive care in dogs. Lab Anim Sci. 48, 513-519. PMid:10090067

28. Gonzáles-Gil, A., Illera, J.C., Silván, G., Illera, M. (2003). Effect of the anaesthetic/tranquillizer treatment on selected plasma biochemical parameters in NZW rabbits. Lab Anim. 37, 155-161. https://doi.org/10.1258/00236770360563804 PMid:12689427

29. Gonzáles-Gil, A., Silván, G., Villa, A., Millán, P., Martínez-Fernández, L., Illera, J.C. (2010). Serum biochemical response to inhalant anesthetics in New Zealand white rabbits. J Am Assoc Lab Anim Sci. $49,52-56$.

30. Schropp, D.M, Kovacic, J. (2007). Phosphorus and phosphate metabolism in veterinary patients. J Vet Emerg Crit Care 17, 127-134.

https://doi.org/10.1111/j.1476-4431.2006.00217.x

31. Ganong, W.F. (2001). Review of medical physiology. 20th ed, (pp. 373-389). McGraw Hill.

32. Schropp, D.M, Kovacic, J. (2007). Phosphorus and phosphate metabolism in veterinary patients. J Vet Emerg Crit Care. 17, 127-134. https://doi.org/10.1111/j.1476-4431.2006.00217.x 